\title{
A Pragmatic Study of Chinese and Western Linguistic Politeness
}

\author{
Mei Wang ${ }^{1}$, Yingying Peng ${ }^{2}$
}

${ }^{1}$ Foreign Language Department, The Engineering \& Technical College of Chengdu University of Technology, Leshan, Sichuan Province, 614000

${ }^{2}$ Sichuan University Jincheng College, Chengdu, Sichuan Province, 611731

\begin{abstract}
Politeness is a social and linguistic phenomenon that exists in almost every culture. Despite its universality, the interpretation and understanding of politeness, the ways to realize politeness, and the standards of judgment differ in different cultures. Based on an analysis of Leech's Politeness Principle and $\mathrm{Gu}$ Yueguo's Politeness Principle, which can represent the Western and Chinese politeness theory model respectively, this paper intends to make a contrastive study of Chinese and Western linguistic politeness in terms of their responses towards praises and compliments, terms of address, privacy and taboo, value and modesty. We find that linguistic politeness strategy bears obvious cultural traits and is largely influenced by its culture, namely, religion, value and ethics etc. The contrastive analysis of the Chinese and Western linguistic politeness can hopefully boost cross-cultural communication.
\end{abstract}

Key Words: linguistic politeness; Politeness Principle; cross-cultural communication

\section{Introduction}

Politeness is the practical application of good manners or etiquette. It is a culturally defined phenomenon, and therefore what is considered polite in one culture can sometimes be quite rude or simply eccentric in another cultural context. While the goal of politeness is to make all of the parties relaxed and comfortable with one another, these culturally defined standards may not only be used to reduce friction and build up a harmonious relationship, but also be manipulated to inflict shame on a designated party at times.

Besides, many languages have specific means to show politeness, deference, respect, or recognition of the social status of the speaker and the hearer. Therefore, politeness is also an important object of study in linguistics. Especially with the rapid development of pragmatics, scholars and linguists home and abroad did massive researches on the polite expressions in different languages form their unique perspectives.
2. Leech and Gu Yueguo's Politeness Principle: Typical Western and Chinese Politeness Theory Model

\subsection{Leech's Politeness Principle}

Leech's work Principles of Pragmatics (1983) elaborates on the Conversational Maxim approach on politeness. Leech says that there exists a set of maxims and sub-maxims that guide and constrain the conversation of people.Leech (1983: 132) sums up six maxims of the Politeness Princople as follows:

(i) Tact Maxim

(a) Minimize cost to other

(b) Maximize benefit to other

(ii) Generosity Maxim

(a). Minimize benefit to self

(b) Maximize cost to self

(iii) Approbation Maxim

(a) Minimize dispraise of other

(b) Maximize praise of other

(iv) Modesty Maxim

(a) Minimize praise of self

(b) Maximize dispraise of self

(v) Agreement Maxim)

(a) Minimize disagreement between self and other

(b) Maximize agreement between self and other

(vi) Sympathy Maxim

(a) Minimize antipathy between self and other

(b) Maximize sympathy between self and other

These maxims have been simplified for convenience by Leech: strictly, i) a), for example, should read: "Minimize the 
expression of beliefs which express or imply cost to other" (1983: 132) and the other maxims should be similarly expanded in that they recommend the expression of polite rather than impolite beliefs. The first four maxims go in pairs because they deal with bipolar scales: the cost-benefit and praise-dispraise scales. The other two maxims deal with unipolar scales: the scales of agreement and sympathy, although they are distinct in that they refer to an evaluative scale which is different from the scales referred to by the other four maxims. Whereas i) and ii) respectively concern the cost or benefit of future action to other and to self, iii) and iv) respectively concern the degree to which speaker's remarks convey some good or bad evaluation of other and of self. For example, the Approbation Maxim is exemplified in the intrinsic courtesy of congratulations, and the Modesty Maxim in that of apologies.

\subsection{Gu Yueguo's Politeness Model}

The serious researches on Chinese politeness did not emerge until the early 1980s. Many Chinese scholars introduced western theories into China and tried to test the validity of these theories. One of the most outstanding scholars who should be mentioned is Gu Yueguo. Gu (1992:10-17) contrasts English politeness phenomenon with Chinese one and proposes his politeness model with five maxims. He demonstrates them as follows:

(i) The self-denigration maxim: This maxim means denigrating self and elevating other. It absorbs the notions of respectfulness and modesty. That is to say, when you are talking about yourself or something about yourself, you are supposed to denigrate yourself and should hold the attitude of being modest. And when you are talking about someone else, you must elevate the one being talked about, and you should show your respect to the addressee. For example, call one's own wife "jiànnèi” while call other's wife "zūnfūrén"; when sending presents, Chinese people often say “xiăo xiăo bó lǐ, bù chéng jìng yì, qǐng xiào nà”; When receiving praise, Chinese people always negate the praise first and then belittle themselves since for Chinese people, accepting other's praise is regarded as self-satisfaction.

(ii) The address maxim: This maxim means addressing your interlocutor with an appropriate address term. It is based on the notions of respectfulness and attitudinal warmth. Gu insists that the address forms represent social relationships among people. Changing of address forms may result in different relationships among certain people.In Chinese, there is a very strict principle in address: "shàng xià yǒu yì, guìjiàn yǒu fền, zhăng yòu yǒu xù". For example, the elder people's name cannot be called directly by younger people.

(iii) The refinement maxim: This maxim means the use of refined language and a ban on foul language, including the use of euphemisms and indirectness. It refers to self's behavior to other which meets certain standards. For example, the word death is always avoided by people. Usually, it is substituted by “chángmián”, "shìshì ”, "lao le", “ānx $\bar{\imath} ”$, otherwise, it will be regarded as impolite; some swear words, sexual bodies and excretion are all regarded as taboos. Therefore when expressing this kind of meaning, one usually use other words or expressions for substitution.

(iv) The agreement maxim: This maxim refers to the efforts made by both interlocutors to maximize agreement and harmony and to minimize disagreement. Take the following dialogue as an example:

A: zhōu rìtú shū guan kāi mén ma? (Will the library open on Sunday?)

B: zhǐyǒu bái chīcái huìzhè me wèn。 (Only idiot will ask questions like that.)

Obviously, the answer of $\mathrm{B}$ is violating the maxim of agreement and the most possibilities is that the conversation cannot carry on continuously.

(v) The virtues-words-deeds maxim: This maxim refers to minimizing cost and maximizing benefit to other at the motivational level, and maximizing benefit received and minimizing cost to self at the conversational level. This type of maxim is just the reflection of Chinese traditional sayings: "yǒu dé zhě bìyǒu yán”, "jūn zǐchǐyǒu qící ér wú qídé, chy̌yǒu qídé ér wú qící".

According to $\mathrm{Gu}$, the self-denigration maxim is unique feature of Chinese politeness. Leech's Modesty Maxim can be considered as one portion of the self-denigration maxim. The address maxim is manifested in address terms, which are very important in Chinese's eyes. They reflect the social relationship 
and relate to the polite behavior. The refinement maxim is universal both in Chinese and other language. Gu claims that the agreement maxim is similar to Leech's Approbation Maxim and Agreement Maxim.

\section{A Comparison of Chinese and British Linguistic Politeness}

\subsection{Different Responses towards Praises and Compliments}

Culture differences are also evident in the ways praises and compliments are expressed and responded. It is noted that people in the West tend to verbalize their praises and compliments more than Chinese speakers and that the westerners tend to accept praises and compliments more directly and frankly than we Chinese do.

For example, many native Chinese speakers will feel embarrassed when they hear compliments like "you speak excellent English." or "You have acquired a native English speaker accent." To show their modesty and that they do not deserve a compliment, is sincere, they are likely to refuse other's praise to themselves by saying "no". Meanwhile, they would like to denigrate self and elevate others to show their respect and compliment to others by saying "you speak better English than I do!".This is in strict accordance with the Self-denigration Maxim of Gu's PP. English speaking people, unlike Chinese, will accept compliment. Therefore, they think it is inappropriate to show false humility, or pretended modesty.

People respond differently to compliments. The reasons, we believe, are partly rooted in culture.It is typical Chinese value to pay much attention to the collectivism and group achievements, so they have a tendency of denying individual's achievement and when they are being complimented, the immediate response of them would be embarrassment and denigration of themselves. For Chinese people, one of the most traditional social norm is to keep being modesty, thus the action of saying "no" in fact does not mean that the recipient of the compliment ignores the appreciations of the speaker, nor that the recipient disagree with the speaker. In reality, Chinese people only want to show that they are modesty and humble. The complimenters, on the other hand, yet would not expect agreements from the recipients of the compliments.
Whereas people under English cultural background tend to accept the compliments in order to avoid embarrassment or disagreement, naturally following the Agreement Maxim proposed by Leech, because theyattach great importance to self, and pay great attention to the equality between self and others. The purpose of people from English-speaking countries to do this is to save the speakers positive face and keep harmonious relationship with other social members of their community.

\subsection{Different Topics in China and West: Taboo and Privacy}

\section{a. Death and illness}

Death is an internal topic in human linguistic taboos; it is regarded as the symbol of unfortunate and horror, whether in east or east, people tend to avoid mentioning it straightly, instead, they use other words for substitute. Whether in ancient or modern china, there are many substitutive ways for death. For example, the death of emperor is called " "jià bēng", "bīn tiān"; the death of noble or dukes is called "hōng"; death for career is called "xī shēng”, “xiàn shēn”, “jiù yì”, “xùn zhí”, “juān qū"; in spoken language, death is called "shì shì" “cháng mián”, "zuò gǔ”, "guī xî̀”, "yǔ shìcháng cí"; in oral language, death is called "bú zài le"; "méi le"; "guò shì le".

Similarly to English people, death is also a taboo. There are many euphemisms for death, such as Joint the silent majority, pass away, go to heaven, fall asleep, pass beyond, fade, be at rest, close one's eyes, breathe the last breath etc.

Words denoting terrible disease are also sources of horror and it is common in linguistic taboos. In Chinese, when we talk to a patient, we may say "nǐ jīn tiān bù shū fu, bié shàng bān le".Here, we use "bù shū fu" instead of "bìng". As a soldier, we may say "guà căi le"instead of "shāng". Mental illnesses are thought not to be mentioned directly. For example, when referring to a mental illness, we just say "yǒu diăn qíguài" or "bú tài zhèng cháng".

In English, they use "V.D" instead of "venereal disease"; use "big C", "long disease", or "terminal illness" to substitute "cancer"; they use "heart condition" to substitute "heart attack"; they use "mentally ill" for replace "mad" and "creasy"; they use "hard of hearing" to replace "deaf" and "visually retarded" for 
"blind". Abbreviations are often used to alleviate the shocking or horrible effect. For example, SARS is used to substitute the terrible name "Severe Acute Respiratory Syndromes".

Euphemisms used to mention death and illness have more similarities than differences due to the same human feeling------horror. Thus both Chinese and English people abide by the same Refinement Maxim proposed by $\mathrm{Gu}$, that is to say, the use of refined language and a ban on foul language. While there still some differences in attitude to death and illnesses. The reasons can be explored as follows:

Western culture is mainly affected by the impact of Christianity; Christians express their living faith through the death of Jesus. They believe that death means returning to the heavenly father in peace. Therefore, their view of death is much more positive than the traditional view of Chinese people. However, people in west are still unwilling to mention death directly, instead, they often use another way. Chinese people' attitude towards death is deeply influenced by Chinese traditional culture--- Confucian culture. Confucian culture advocates people to be practical; to enjoy sensitive life; to be responsible for life; to pay all attention on seeking to social value and never think the problem of death. In a sense, this confusion culture of excluding death from sight of life is one of the cultural sources from which Chinese people always worry about or fear death. Therefore, behind every Chinese people's back hides a very deep sorrow and fear for death because death means completely negation of living; completely shattering of pleasure of real life, as a result, it is undoubtedly a heavy blow for Chinese people who pay much attention to reality. Therefore, death is a forbidden topic inChinese traditional culture and not only the word death can't be mentioned directly but words related to death can also not be mentioned, even if they have the same or similar pronunciation, for example, when you present gifts to others, you had better not to give clock because "zhōng (clock)" has the same pronunciation with"zhōng (end)"which means end.

\section{b. Privacy}

Privacy is a common phenomenon which exists in every culture; however, different cultures have different views on privacy.

Chinese people are believed not to be very sensitive to privacy. So people feel free to ask almost any question without being offensive. The most common topics are age, income, property, family life, politics and religion. Also, when a purchase, is made, Chinese people will often ask or voluntarily tell the item's price in order to share the happiness of having a good bargain. In China when two people first meet each other, they will ask many questions to each other. After three minutes, they will know each other very well. They have got much private information clearly from each other, including family situation, individual condition. Chinese people don't take the privacy so seriously as the westerners do. They like to ask some questions to show their concern about others.

While the westerners pay much attention to preserving their privacy; they define privacy as freedom from unauthorized intrusion, from which it can be seen that the westerners view privacy as a kind of human rights which cannot be invaded freely. The English proverb "A man's home is his castle" and "mind your own business" seems to be a good example to show the significance of privacy. For most westerners, their age, income, marriage, religious belief all belongs to privacy. Therefore, when talking to westerners, you are forbidden to ask questions such as "how old are you?";"how much do you make?";“'why don’t you get married?". Westerners' common and "safe" topics are weather, sports, news, traveling, interests and hobbies. They are reluctant to answer personal questions about age, weight, illness, income, property, religion and politics.

The westerners' view on privacy is affected by individualism. Individualism is a core value in American culture. It refers to the doctrine that the rights of the individual are the most important ones in a society. Most westerners believe that each person has his own separate identity and personality, which should be recognized and reinforced. The core of individualism is the pursuit of personal achievements which is highly valued, earnestly believed and well appreciated as a fundamental social virtue. In Christianity traditions, individuals are important not only to each other, but also to the society and God. Individualism has been handed down from their ancestors. Therefore, to westerners, individualism is not selfishness but 
rather virtue. They emphasize individualism so much that they believe that there must be something wrong with someone who fails to demonstrate individualism.

The Chinese view on privacy is affected by collectivism. It emphasizes cooperation among group members and individual success is due to the collective effort of the staff in a unit, an organization or a community. The sacrifice of individual interest for that of the collective is a noble quality eulogized so much by Chinese people that being modest and thoughtful of others are highly praised. Another reason is that most parts of china are rural areas and people usually live closely together in a small area from one generation to generation. They help each other in living and share happiness and sorrow together; there seems to be no topics discussed, thus they have no secret each other. They can ask any questions they like.

\subsection{Greetings and Terms of Address}

\section{a.Greetings}

It is estimated that in English there are at least a dozen different greetings, from "Hi" and "Hello" to more specific and longer ones like "How are you getting on?" or "How is everything with you?" People choose the proper one to greet different people they meet on different occasions. For example, people greet a new acquaintance with "How do you do?" and expect the same in answer, but they greet an old friend differently. When friends meet, you may find more than once they are uttering" How are you?" at the same time to each other, and they both answer "Fine, thank you." Differently, a Chinese speaker may greet his friends or new acquaintance with "Nin hao" or "Nihao", whether they meet for the first time or anytime in the day.

Another noticeable difference between the two greeting systems is that most Chinese people tend to greet acquaintances with "You are fat" or "You are so thin, Please pay more attention to your health.". When the two friends meet, they often say, "Where are you going? "or "Have you had the meal? "In Chinese culture, it shows tactful, friendly and warmly. Because when a Chinese speaker says hello to an English speaker using these phrases, English speaker sometimes thinks it is an "inquiry" not the friendly"greeting".

\section{b.Address Terms}

According to $\mathrm{Gu}$ Yueguo, Chinese people tend to use different addressing terms to show respectfulness and attitudinal warmth (Gu, 1990: 248-249). Here we would discuss the differences between English and Chinese addressing terms mainly from two aspects: personal names, kinship terms.

\section{(a)Personal Names}

Usually, an English name is composed of a first name, i.e., the given name or the Christian name, a middle name, and a last name which is the family name or surname. Western people may call other's first name even at the first time they meet after making acquainted with each other. While in China, given names may be just used between people of the same social status within the same sex. For people who are with Chinese cultural background, the use of given names reflects that the relationship between the speaker and the hearer is very close. So in a traditional sense of Chinese culture, only very close friends or spouses have the privilege to address the counterpart in an interlocution by the hearer's first name.

In China, "tong zhì" was once used for all people irrespective of sex, position or marital status, while in English -speaking communities "Mr." "Mrs." "Miss." "Ms." would be appropriate in similar situations. It is also interesting to note that in recent years "Mr." and "Miss." are picked up again to replace "tong zhì" with the changes in society. Meanwhile "shī fu" is frequently used to show respect for strangers. English speakers, on similar occasions, would use "Sir" or "Madam".

\section{(b)Kinship Terms}

As is known to all, Chinese kinship terms are much more complicated than that of English. The Chinese counterparts of the English kinship terms like "cousin, father-in-law, uncle" are of various kinds. So we may assume that English kinship terms are kind of vogue, while that of Chinese are relatively concrete.

Chinese people have tremendous numbers of kinship terms to describe specific kinship relations. Kinship terms from both the paternal side and the maternal side are described unmistakably. For instance, Chinese people have a variety of terms to address the relatives from the mother side such as "yi" 
(sisters of mother), "wài pó"(grandmother from the maternal side), and "jiù jiù"(uncles from the maternal side). And the corresponding forms from the paternal side are "gū gū" (father's sisters), "zǔ mǔ" (grandmother from the paternal side), and "shū shū/dà yé" (uncles from the paternal side). Traditionally, paternal kinship is much more important than maternal kinship though they are of equal importance in the aspect of bloodline. What reflects this is that Chinese people often use the term "yé ye, năi nai" to address someone strange to them in consideration of politeness. On the contrary, the kinship term "lăo lao, lăo yé" cannot be used in this way. A deep-rooted reason account for this phenomenon is Chinese long history of sexual discrimination against women. Though female position in China today has been elevated very much and in some families even higher than man, this remnant custom cannot be changed at all. Besides, age is also an important factor for Chinese kinship address terms. People from older generations can address the younger generations just by their names, but this does not applies vice versa.

\section{Conclusions}

All in all, the Chinese and Western linguistic politeness has both its universalities and characteristics. The reasons, as we argue here, are deeply rooted in culture. Chinese people and society are greatly influenced by Confucianism, which emphasizes virtue, se1f1essness, duty, patriotism, hard work and respect for hierarchy and infiltrate in Chinese people the idea of hierarchy and collectivism. Christianity, which places a high value on individualism, liberty and justice, is the core of western civilization. Therefore, most Westerners are strong adherers of freedom, independence, equality and self-realization. All those cultural differences are reflected in language and also verbal expressions of politeness.

\section{REFERENCES}

[1]. Gu Yueguo. Politeness, Pragmatics and Culture[J]. Foreign Language Teaching and Research, 1992(4).

[2]. Gu Yueguo. Western classical rhetoric and Western New Rhetoric Theory $[\mathrm{J}]$. Foreign Language Teaching and Research, 1990(2).

[3]. He Zhaoxiong. A Study of Politeness in Chinese and English Cultures [J]. Foreign Language, 1995(5).

[4]. Leech, Geoffrey. Semantics: The Study of Meaning [M]. London: Longman, 1981.

[5]. 5. Leech, Geoffrey. Principles of Pragmatics [M]. London: Longman,

1983. 